\title{
Subsurface irrigation by condensation of humid air
}

\author{
J. Lindblom \& B. Nordell \\ Department of Civil and Environmental Engineering, \\ Luleå University of Technology, Sweden
}

\begin{abstract}
Condensation Irrigation (CI) is a combined system for solar desalination and irrigation. Solar stills are used to humidify ambient air flowing over the saline water surface in the stills. This warm, humid air is then led into an underground system of drainage pipes where it is cooled and vapour precipitates as freshwater. The condensed water and some humid air percolate through the pipe perforations and irrigate and aerate the ground. Mass and heat transfer in the soil-pipe system has been modelled to evaluate the theoretical productivity for these types of systems. For a presumed pipe configuration and climate, $3.1 \mathrm{~kg}$ water per pipe-meter and day was condensed inside the buried pipe, yielding $2.3 \mathrm{~mm} / \mathrm{d}$ irrigation water. Pilot plants on the CI system and are now in operation in Tunisia and Algeria. Another CI plant is planned in Libya.

Keywords: condensation, irrigation, subsurface, solar driven, desalination, modelling, mass and heat transfer.
\end{abstract}

\section{Introduction}

The accelerating land degradation and declining agricultural productivity in Africa constitute major problems for its population's future economic and food security. Predictions indicate that the continent only will be able to feed $40 \%$ of its population in another 20 years [1]. Since only $10 \%$ of the African land has the potential of rain-fed cultivation, and since water availability often is the most limiting factor for root growth [2], irrigation expansion is of highest importance for Africa's future development. However, more than $90 \%$ of the available freshwater is already used for irrigation in some parts of Africa [3], and groundwater tables in some areas are dropping rapidly due to increasing tube well installations [4]. 
The only sustainable way to produce more freshwater is through desalination of seawater. In oil rich countries such as Kuwait, Saudi Arabia, and the United Arab Emirates, about $95 \%$ of all freshwater is already supplied by desalination technologies using fossil fuels [5]. In view of future oil shortages, desalination must, however, be driven with renewable energy.

Solar powered desalination is an obvious choice for remote and sunny regions as it is reliable, environmentally sound, and easily maintained [6]. The main problems with using solar thermal in large-scale desalination plants are relatively low production rates (about $3-4 \mathrm{~kg} / \mathrm{m}^{2} / \mathrm{d}$ in passive solar stills [7]), low thermal efficiency and the considerable land area required [8].

However, because the plants are also characterised by free energy and an insignificant operating cost, the technology is suitable for small-scale production, especially in remote arid regions and islands, where conventional energy and the supply of freshwater is erratic, but the solar potential is high [9].

\subsection{Condensation Irrigation}

In the Condensation Irrigation (CI) system ambient air is warmed and humidified when flowing over a saline water surface in solar stills. The air is then led into an underground pipe system, where it is cooled and vapour precipitates as freshwater on the inner walls of the pipes.

Using drainage pipes to conduct the airflow enable the condensed water and some humid air to infiltrate the ground around the pipes, thereby irrigating and aerating it. If non-perforated pipes are used, the formed freshwater can instead be collected at the pipe endings and used for e.g. drinking. The CI system is outlined in Figure 1.

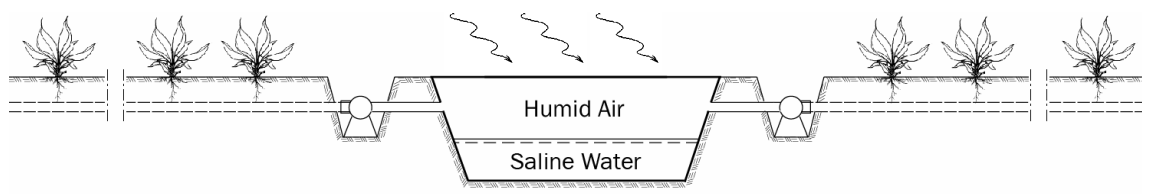

Figure 1: Outline of a condensation irrigation system. Ambient air flows over the solar heated saline water surface in solar stills and led into buried pipes, where it is cooled and vapour precipitates as freshwater.

The condensation process in the pipes occurs during the hours when the sun is able to evaporate water inside the stills. As the air dehumidification inside the pipes proceeds during the day, the surrounding ground gradually becomes heated, resulting in a reduced condensation rate. To enhance the condensation rate the succeeding day, cool air is circulated through the pipes at night.

Due to the low-flow irrigation water distribution occurring throughout the day, water uptake by crops should be efficient and the risk for land degradation is greatly reduced. The sub-surface irrigation scheme also contributes to a reduced water loss through surface evaporation and run-off and deep percolation 
due to flooding. Since the air heating and humidification is solar driven, more irrigation water is formed inside the buried pipes on sunny days, when the irrigation need is high.

Although solar stills are suitable for humidifying air, many other methods and heat sources are possible, depending on the geography and other site specific conditions. A solar driven alternative would be to use existing lined irrigation canals that are impermeable to salts. Converting these to air humidification canals would require a transparent cover and possibly a radiation absorbing material onto the canal borders.

Work concerning the Condensation Irrigation system started at the Lulea University of Technology (LTU) as a series of Masters Theses [10-12], and the technology was used in the construction of a greenhouse climate control facility in Övertorneå, Sweden [13].

Independently of these studies, the Swiss company Ingenieurbüro Ruess und Hausherr constructed a CI plant where seawater had evaporated in plastic tubes, with the condensation occurring in buried drainage pipes. A reported $50 \%$ reduction in the water consumption of tomato plants was observed in the system [14].

Recent studies on Condensation Irrigation has involved theoretical analyses on one drinking water system and one sub-surface irrigation system using buried drainage pipes $[15,16]$.

\section{Subsurface Condensation Irrigation}

To examine the potential for the Condensation Irrigation (CI) system a theoretical simulation model of air dehumidification inside buried drainage pipes was developed in Matlab using a transient finite difference scheme in three dimensions.

In the simulations, the air was dehumidified for 12 hours each day using constant airflow properties at the pipe inlet (Table 1). The rest of the day was devoted to nightly ground cooling, when cool ambient air at varying temperatures was circulated through the pipes. The pipe configuration in the models comprised 50 meter long parallel pipes placed 1.0 meter apart at 0.5 meter's depth $[15,16]$ in a soil with properties set according to Table 1 .

The heat and mass transfer in the soil-pipe system were simulated for a period of three months, during which time the diurnal mean condensation rate and vapour flux through the perforations in the $50 \mathrm{~m}$ long pipe varied according to Figure 2 .

The daily condensation rate in the reference system soon became steady at $3.1 \mathrm{~kg} / \mathrm{m}$ pipe and day as the soil temperature around the pipe seized to increase from one day to another. Since the pipe spacing was set to $1.0 \mathrm{~m}$ this corresponds to $3.1 \mathrm{~mm} / \mathrm{d}$ irrigation yield. During the nightly ground cooling with colder and drier air, some of the formed irrigation water re-entered the pipes. In the reference system the resulting irrigation yield was for this reason reduced to 2.3 $\mathrm{mm} / \mathrm{d}$. 
Table 1: $\quad$ Properties of the sand and airflow at the inlet.

\begin{tabular}{llrr}
\hline \multirow{2}{*}{$\begin{array}{l}\text { Humid air at } \\
\text { pipe inlet }\end{array}$} & Temperature, $\mathrm{T}_{\mathrm{av}, \text { in }}$ & 60 & ${ }^{\circ} \mathrm{C}$ \\
& ${\text { Relative humidity, } \phi_{\mathrm{av}, \text { in }}}^{*}$ & 70 & $\%$ \\
& Velocity, $_{\mathrm{av}, \text { in }}$ & 3.5 & $\mathrm{~m} / \mathrm{s}$ \\
\hline \multirow{3}{*}{ Sandy soil } & Porosity, $\theta$, & 0.43 & $\mathrm{~m}^{3} / \mathrm{m}^{3}$ \\
& Residual water saturation, $\mathrm{S}_{\mathrm{r}}$ & 0.10 & $\mathrm{~m}^{3} / \mathrm{m}^{3}$ \\
& van Genuchten parameter, a & 6.9 & $\mathrm{~m}^{-1}$ \\
& van Genuchten parameter, $\mathrm{n}$ & 4.6 & - \\
& Intrinsic permeability, $\mathrm{k}_{\mathrm{i}}$ & $10^{-12}$ & $\mathrm{~m}^{2}$ \\
& Tortuousity coefficient, $\tau$ & 0.62 & - \\
\hline
\end{tabular}

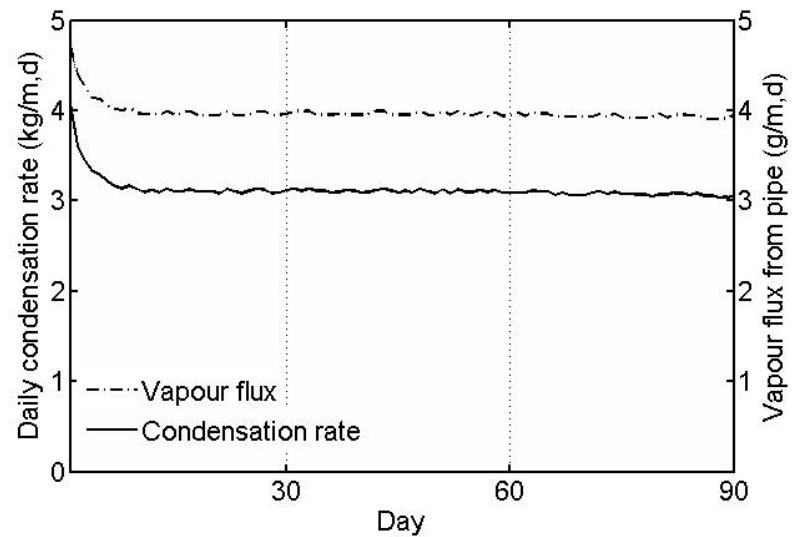

Figure 2: Mean condensation rate (-), and vapour flux through perforations (-•-.--), per pipe meter of a buried drainage pipe during the first 90 days of irrigation in the reference system.

The potential evapotranspiration (PET) from irrigated crops usually range between 4 and $7 \mathrm{~mm} / \mathrm{d}$ [17], which is significantly more than the irrigation yield in the simulated reference system. It should however be noted that including plants in the simulations would increase the water added to the soil since root suction enhance water movement in the soil, thus lowering the ground temperature and increasing the condensation rate in the pipes.

Solar radiation was excluded from the models, which resulted in the ground being cooled from above. The irrigation water from the buried drainage pipes therefore experienced an upward motion, accumulating in the soil above and around the pipe. Figure 3 shows the soil water saturation and liquid water flux density in the cross-section at $25 \mathrm{~m}$ distance from the pipe inlet.

The air dehumidification process inside the pipes heated the ground in the pipe's surrounding, influencing not only the water production inside the pipes, but also crop root development. 

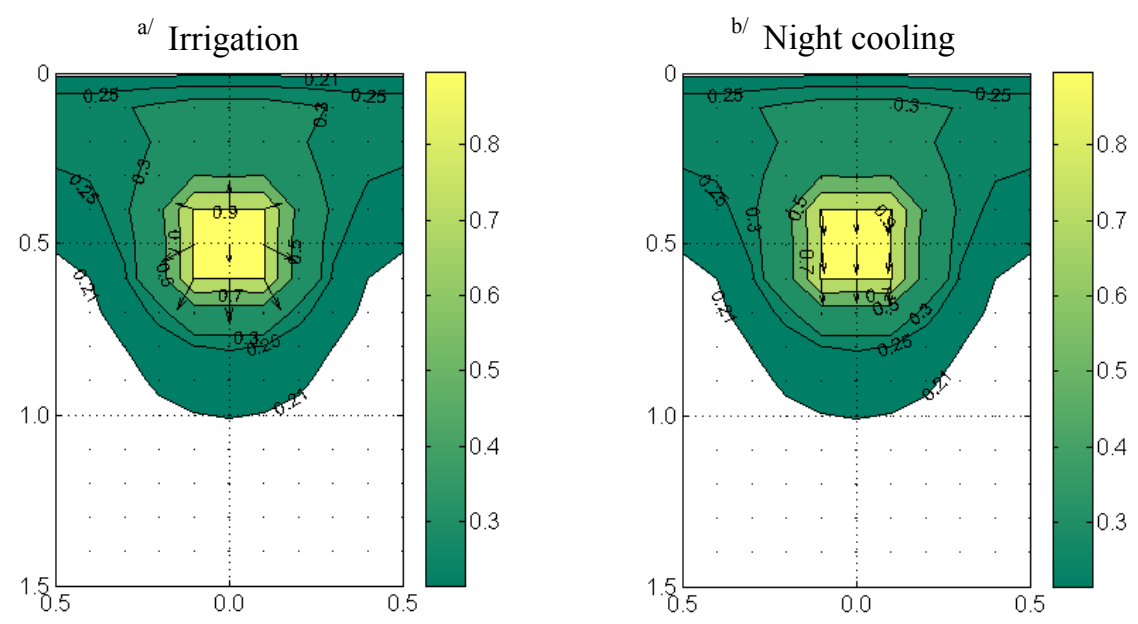

Figure 3: Soil water saturation and liquid water flux density in the midsection of the pipe during the $6^{\text {th }}$ hour of ${ }^{\text {a) }}$ irrigation and ${ }^{\text {b) }}$ night cooling on the $91^{\text {st }}$ day.

Generally, the optimum temperature interval for roots is about $17-35^{\circ} \mathrm{C}$ [18], and higher temperatures may injure or destroy them. In the CI system, the temperature at the pipe walls should therefore exceed this interval in order to prevent roots from growing into the pipes and block the airflow. The soil temperature in the rooting zone between the pipes must however always be tolerable for the roots.

The cross-sectional soil temperature distribution and vapour flux density $25 \mathrm{~m}$ along the buried drainage pipe is shown in Figure 4 for the sixth hour of irrigation and night cooling at steady diurnal condensation rate.

During the daily air dehumidification, some vapour from the humid airflow infiltrated to the soil through the pipe perforations resulting in an increased vapour flux density away from the pipe. At night, the cool ambient air circulating inside the pipes gave rise to an opposite direction of vapour flux density near the pipe wall, thereby reducing the irrigation yield.

In the simulated reference system the soil between the pipes was $35-40^{\circ} \mathrm{C}$, which is too warm for crops. To reduce the soil temperature the pipes could be placed further apart, which also increase the condensation rate in the pipes further. Doubling the spacing in the reference pipe configuration previously described resulted in approximately $5^{\circ} \mathrm{C}$ cooler ground in the rooting zone and a mean condensation rate of $3.3 \mathrm{~kg} / \mathrm{m} / \mathrm{d}$. The irrigation yield using $2.0 \mathrm{~m}$ spacing was reduced to $1.4 \mathrm{~mm} / \mathrm{d}$ due to the larger soil volume each pipe had to irrigate.

When studying the presumed parameters in the simulated CI system it was apparent that the presumed inlet airflow properties, in particular the inlet airflow temperature, had the greatest effect on the resulting condensation rate in the pipe. 
The high temperature dependence of the condensation rate is mainly due to the temperature driven mass transport in the soil matrix, which increases as the temperature difference between the pipe and the surrounding increase.

In Table 2 the mean condensation rate is shown for simulations where the inlet air temperature, humidity and velocity has been increased or reduced $20 \%$ from the reference value specified in Table 1 .
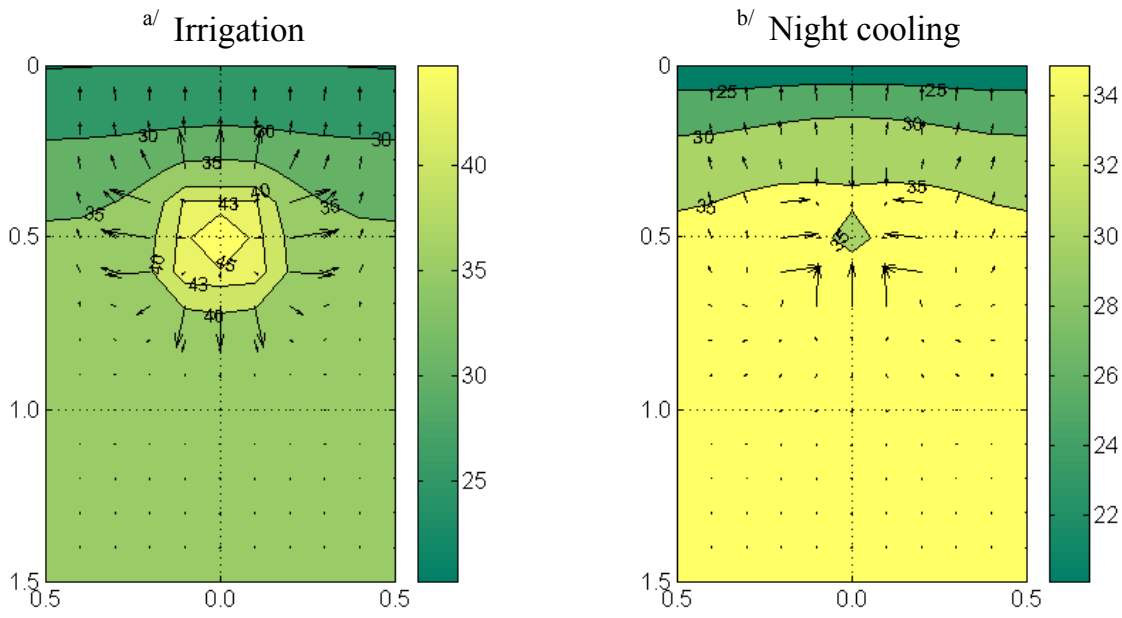

Figure 4: Temperature and vapour flux density in the midsection of the pipe during the $6^{\text {th }}$ hour of ${ }^{\text {a) }}$ irrigation and ${ }^{\text {b) }}$ night cooling on the $91^{\text {st }}$ day. The centre of the $0.2 \mathrm{~m}$ diameter drainage pipe is located at $0.5 \mathrm{~m}$ depth.

Table 2: Dependence of mean condensation rate on humid air properties at the pipe inlet.

\begin{tabular}{lllll}
\hline Inlet air parameter & $+20 \%$ & \multicolumn{3}{l}{$-20 \%$} \\
\hline Temperature & $5.86 \mathrm{~kg} / \mathrm{m} / \mathrm{d}$ & $(+90 \%)$ & $1.12 \mathrm{~kg} / \mathrm{m} / \mathrm{d}$ & $(-63 \%)$ \\
Relative humidity & $3.89 \mathrm{~kg} / \mathrm{m} / \mathrm{d}$ & $(+26 \%)$ & $2.19 \mathrm{~kg} / \mathrm{m} / \mathrm{d}$ & $(-30 \%)$ \\
Velocity & $3.48 \mathrm{~kg} / \mathrm{m} / \mathrm{d}$ & $(+11 \%)$ & $2.71 \mathrm{~kg} / \mathrm{m} / \mathrm{d}$ & $(-13 \%)$ \\
\hline
\end{tabular}

Increasing the inlet airflow temperature from 60 to $72^{\circ} \mathrm{C}$ led to $90 \%$ higher condensation rate, and $4.1 \mathrm{~mm} / \mathrm{d}$ of irrigation yield to the soil. The temperature in the rooting zone was however raised to $40-50^{\circ} \mathrm{C}$, which far exceeds the tolerable temperature levels for crop roots. When these high airflow temperatures are achievable from the air humidification, the pipes must therefore be placed wide apart. 


\section{Field testing and experiments}

To evaluate the developed theoretical model, a small-scale indoor test rig has been constructed at Luleå University of Technology (LTU), Sweden. The setup is designed to resemble the boundary conditions and presumptions used in the numerical simulations of the described subsurface CI system [19].

Measuring the humid airflow properties inside a drainage pipe, and logging the temperature and humidity distribution in a cross-section of the surrounding uniform sand, provides an estimation of the heat and mass transport in that crosssection and the resulting condensation rate in the pipe. Experiments and validations of theoretical models are at present being conducted at LTU.

Pilot plants of Condensation Irrigation systems have been constructed in Tunisia and Algeria. Measurements from these plants will in future research be used for evaluating the feasibility of Condensation Irrigation. A second test plant will be constructed in Tunisia inside a greenhouse during 2006 in order to improve the accuracy of the measurements (Figure 5).

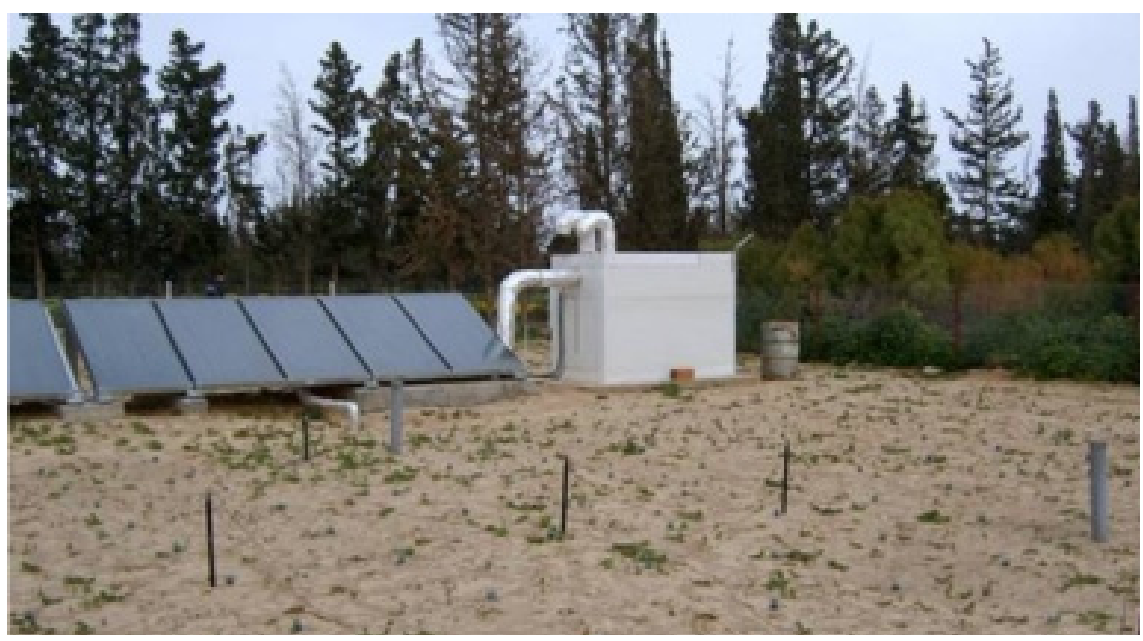

Figure 5: Pilot plant at the INRGREF in Tunisia. Ambient air is heated and humidified using solar collectors. The soil temperature and humidity are measured in the ground around drainage pipes.

\section{Conclusion}

Condensation Irrigation (CI) is a combined system for solar desalination and irrigation, in which solar stills are used for humidifying ambient air. The warm and humid air is led from the still into an underground pipe system where it is cooled and vapour precipitates as freshwater on the pipe walls. If drainage pipes are used the water and some of humid air percolate through the pipe perforations and irrigates and aerates the ground. 
Mass and heat transfer in the soil around the buried pipes has been modelled in Matlab for a subsurface irrigation system. From the theoretical models it was concluded that $\mathrm{CI}$ could be used for irrigation at relatively low operational costs. The simulations of the subsurface irrigation resulted in a diurnal steady state condensation rate of $3.1 \mathrm{~kg} / \mathrm{m} / \mathrm{d}$ and a mean irrigation yield of $2.3 \mathrm{~mm} / \mathrm{d}$.

The CI system has attracted attention from several North African countries. Pilot plants are now in operation in Tunisia and Algeria where LTU is collaborating with the Tunisian Institute for Research on Rural Engineering, Water and Forestry and the University of Tlemcen in Algeria. LTU is also collaborating with Al Fatah University and the International Energy Foundation in Tripoli, Libya. Ongoing work aims at developing a design tool and monitoring program for the CI system to be used in the design and operation of a demonstration plant in Libya.

\section{References}

[1] UNEP (United Nations Environment Programme), Global Environment Outlook 2000, Nairobi, Kenya, www.grida.no/geo2000/.

[2] L. Karlberg, Irrigation with saline water using low-cost drip-irrigation systems in Sub-Saharan Africa. Doctoral Thesis, KTH publication TRITA-LWR PhD Thesis 1020: Stockholm, 2005.

[3] Hamdy A., Ragab R., Scarascia-Mugnozza E., Coping with water scarcity: Water saving and increasing water productivity. Irrigation and Drainage, $\mathbf{5 2}$ pp. 3-20, 2003.

[4] Plusquellec H., Is the daunting challenge of irrigation achievable? Irrigation and Drainage, 51, pp. 85-198, 2002.

[5] Chaibi M.T., An overview of solar desalination for domestic and agriculture water needs in remote areas. Desalination, 127, pp. 119-133, 2000.

[6] Fath H.E.S., Solar distillation: a promising alternative for water provision with free energy, simple technology and clean environment. Desalination, 116, pp. 45-56, 1998.

[7] Kalogirou S., Survey of solar desalination systems and system selection. Energy, 22, pp. 69-81, 1997.

[8] Naim M.M.\& Abd El Kawi M.A., Non-conventional solar stills Part 1: Non-conventional solar stills with charcoal particles as absorber medium. Desalination, 153, pp. 55-64, 2002.

[9] Kunze, H., A new approach to solar desalination for small- and mediumsize use in remote areas. Desalination, 139, pp. 35-41, 2001.

[10] Widegren M., Condensation Irrigation, a desalination-irrigation system, Master Thesis 1986:002E, Luleå University of Technology: Sweden, 1986.

[11] Göhlman A., Heating of frozen ground. (Uppvärmning av frusen mark), Master Thesis 1987:030 E, Luleå University of Technology: Sweden (in Swedish), 1987. 
[12] Gustafsson A.M. \& Lindblom J., Underground Condensation of humid Air - a Solar Driven System for Irrigation \& Drinking-water production, Master Thesis 2001:140 CIV, Luleå University of Technology: Sweden, 2001.

[13] Nordell B., Design of Climate System for Greenhouse in the North of Sweden. (Dimensionering av klimatsystem vid Hietalas växthus i Övertorneå), Luleå University of Technology: Sweden (in Swedish), 1987.

[14] Hausherr B. \& Ruess K., Seawater desalination and irrigation with moist air, Ingenieurbüro Ruess und Hausherr, Switzerland, 1993.

[15] Lindblom J. \& Nordell B., Water Production by Underground Condensation of Humid Air. Desalination, 189, pp. 248-260, 2006.

[16] Lindblom J. \& Nordell B., Condensation Irrigation - a system for desalination and irrigation, submitted to Transport in Porous Media, 2006

[17] Nyvall J., Controlled drainage / subirrigation. BC Ministry of agriculture and food: Abbotsford, BC, 1998.

[18] Doussan C., Pagès L., Pierret A., Soil exploration and resource acquisition by plant roots: an architectural and modelling point of view. Agronomie, 23, pp. 419-431, 2003.

[19] Lindblom J., Condensation Irrigation - simulations of heat and mass transfer, Licentiate Thesis 2006:08, Luleå University of Technology: Sweden, 2006. 